\title{
Enzymatic degradation of biostatic materials based on polylactide
}

\author{
Agnieszka Richert $^{{ }^{*}}$, Ewa Olewnik-Kruszkowska ${ }^{2}$ \\ ${ }^{1}$ Institute for Engineering of Polymer Materials and Dyes, M. Skłodowska-Curie $55 \mathrm{St}$, \\ 87-100 Toruń, Poland, "e-mail: a.richert@impib.pl \\ ${ }^{2}$ Nicolaus Copernicus University, Faculty of Chemistry, Chair of Physical Chemistry and Physicochemistry \\ of Polymers, Gagarin 7 St, 87-100 Torun, Poland
}

Received: 2 March 2018 / Accepted: 30 April 2018

\begin{abstract}
The paper presents the research results for enzymatic degradation of biodegradable materials in proteinase K. Polylactide and its composites containing a biostatic substance in the form of sulphanilic acid salt PHMG were tested as part of the research project. Three different concentrations of the biostatic substance were used: $0.2 \%, 0.6 \%$ and $1.0 \%$ of the mass. The research results of differential scanning calorimetry (DSC) for the tested materials were compared both before and after the enzymatic degradation. Photographs obtained from a scanning electron microscope (SEM) and the analysis of the foil physical mass loss confirmed that these materials were susceptible to enzymes.
\end{abstract}

Key words: enzymatic degradation, proteinase $K$, polylactide, PHMG.

\section{Introduction}

The natural environment is more and more often monitored for the presence of plants, microorganisms and lichen in certain areas, including degraded areas and areas polluted by the industry (Adamska et al., 2015). There is also a relationship between those data and environmental pollution caused by polymer waste. It is due to the growing global interest in environmental protection that the polylactide (PLA) is becoming more and more valuable as a polymer material used in both scientific research and in the packaging industry. Due to its properties, PLA can be used as a material in various applications. The major areas of its application include objects of common use and medical equipment. The materials of common use include containers and packaging foil used in farming and gardening. The medical equipment includes, among others, bioresorable implants, surgical thread, medical clothing as well as sanitary materials and dressings. Capsules used for slow release of medicines were one of the first areas where PLA was applied (Lin et al., 2007). PLA is a completely biodegradable polymer in the conditions of industrial composting and it is completely assimilable by living organisms (Duda, 2003; Duda \& Penczek, 2003; Schlegel, 2003).

Polyhexamethylene guanidine (PHMG) and its derivatives is one of the bactericidal substances which can be applied with polymer materials. PHMG, both in the form of a free base and salt of inorganic acids, has very good water-soluble properties and it shows germicidal as well as disinfecting properties. PHMG derivatives have been applied as disinfectants, antiseptics as well as biocides giving bacteriostatic or biocidal properties to various polymer materials (Vointseva et al., 2006).

Proteinase $K$ (E.C.3.4.21.64) is a serine protease belonging to the hydrolase class and it is synthesized by Engyodontium album cells (synonym: Tritirachium album) ATCC 22625 (Hildebrandt et al., 2008; http://www. mycobank.org). This fungus is a potential organism used in biodegradation due to its possibility to produce and secrete degrading enzymes (Jeyakumar et al., 2013). The 
research topics dealt with in this paper is a continuation of the work on bacteriostatic and germicidal materials (Richert, 2017a, b).

The aim of this paper is to determine the impact of a biostatic additive in the form of a polyhexamethylene guanidine derivative (i.e. sulphanilic acid salt PHMG) on the loss of mass, change of crystallinity and the surface structure of biostatic foil under the influence of an enzyme solution containing proteinase $K$.

\section{Material and methods}

The research focused on two-component biodegradable foil made of 2003 D type polylactide (PLA) (NatureWorks ${ }^{\circledR}$, USA) and a biostatic substance in the form of sulphanilic acid salt PHMG prepared at the Branch of Dyes and Organic Products in Zgierz (currently Institute of Leather Industry in Łódź) (Górecki et al., 2011; Wyrębska et al., 2012).

Before enzymatic degradation, polylactide samples were marked with the symbol B and the composites containing sulphanilic acid salt PHMG were marked with the symbol BS (Table 1).

Table 1. Marking and content of individual samples

\begin{tabular}{|c|c|}
\hline Sample & $\begin{array}{c}\text { Content of sulphanilic acid } \\
\text { salt PHMG } \\
\mathbf{( \% )}\end{array}$ \\
\hline B & - \\
\hline BS02 & 0.2 \\
\hline BS06 & 0.6 \\
\hline BS1 & 1.0 \\
\hline
\end{tabular}

After the process of enzymatic degradation, samples of the foil were marked with the same symbols with the additional symbol "2e."

Samples of the foil with the dimensions of $15 \times 15 \times$ $0.8 \mathrm{~mm}$ were used for the tests in solutions of proteinase $K$ enzymes. The tests were done according to the research method described by Nagata et al. (1996). The reactions of enzymatic degradation were performed in an enzymatic solution consisting of $10 \mathrm{~cm}^{3}$ of $0.1 \mathrm{M}$ Tris- $\mathrm{HCl}$ buffer with $\mathrm{pH} 8,2 \mathrm{mg}$ of the enzyme being tested and $2 \mathrm{mg}$ of sodium azide (a factor inhibiting bacterial growth and development of fungi). The tested samples were immersed in a solution with the constant temperature of $37^{\circ} \mathrm{C}$ maintained during the whole test process.
In order to define the possible impact of the liquid environment of the reaction on the loss of sample mass, measurements of control samples were taken. Those samples were immersed in the same solution as the solution prepared for the degradation in enzyme solutions, but with one exception. The solution did not contain enzymes.

After two months of incubation, the measurements of mass loss were taken with the application of weight method. The samples taken from the solutions were washed with distilled water and dried.

The loss of mass $(\Delta \mathrm{m})$ was calculated according to formula (1) and expressed as a percentage:

$$
\Delta \mathrm{m}=\left\{\left(\mathrm{m}_{\mathrm{s}}-\mathrm{m}_{\mathrm{f}}\right) / \mathrm{m}_{\mathrm{s}}\right\} \cdot 100[\%]
$$

where:

$\mathrm{m}_{\mathrm{s}}$ - the initial mass of the samples,

$\mathrm{m}_{\mathrm{f}}$ - the mass of samples after enzymatic degradation.

After the process of enzymatic degradation, tests were also performed to determine the changes in the surface properties of the foil used with the application of scanning electron microscopy (SEM). The Hitachi SU8010 scanning microscope (Hitachi, Japan) was used in those tests.

The content of the crystalline phase $(\chi)$ (crystallinity) was determined thanks to scanning tests of DSC differential calorimetry performed in accordance with the PN EN ISO 11357 (2002) standard and thanks to calculations according to formula (2):

$$
\left.\chi=\left\{\left(\mathrm{H}_{\mathrm{m}}-\mathrm{H}_{\mathrm{c}}\right) / \mathrm{H}\right)\right\} \cdot 100[\%]
$$

where:

$\mathrm{H}_{\mathrm{c}}$ - enthalpy of cold crystallization determined during DSC tests,

$\mathrm{H}$ - enthalpy of melting for a given polymer containing $100 \%$ of the crystalline phase (it was assumed that for the polylactide the enthalpy value of a completely crystallized PLA was equal to $96 \mathrm{~J} / \mathrm{g}$ ).

\section{Results}

Figure 1 shows the results of the loss of mass of foil samples B-2e, B02-2e, B06-2e and B1-2e exposed to the action of proteinase $K$.

The figure shows that the biggest mass loss in the samples was observed after a maximum period of incubation for samples B and BS1 in the solution of proteinase $K$, i.e. after two months of enzymatic degradation. The sample foil made of pure polylactide underwent the fastest process of degradation. For samples B, BS02, BS06 and BS1 the loss of mass after two months' incubation in the enzyme solution amounted to $42 \%, 5.2 \%, 6.6 \%$ and $7.9 \%$ respectively. 


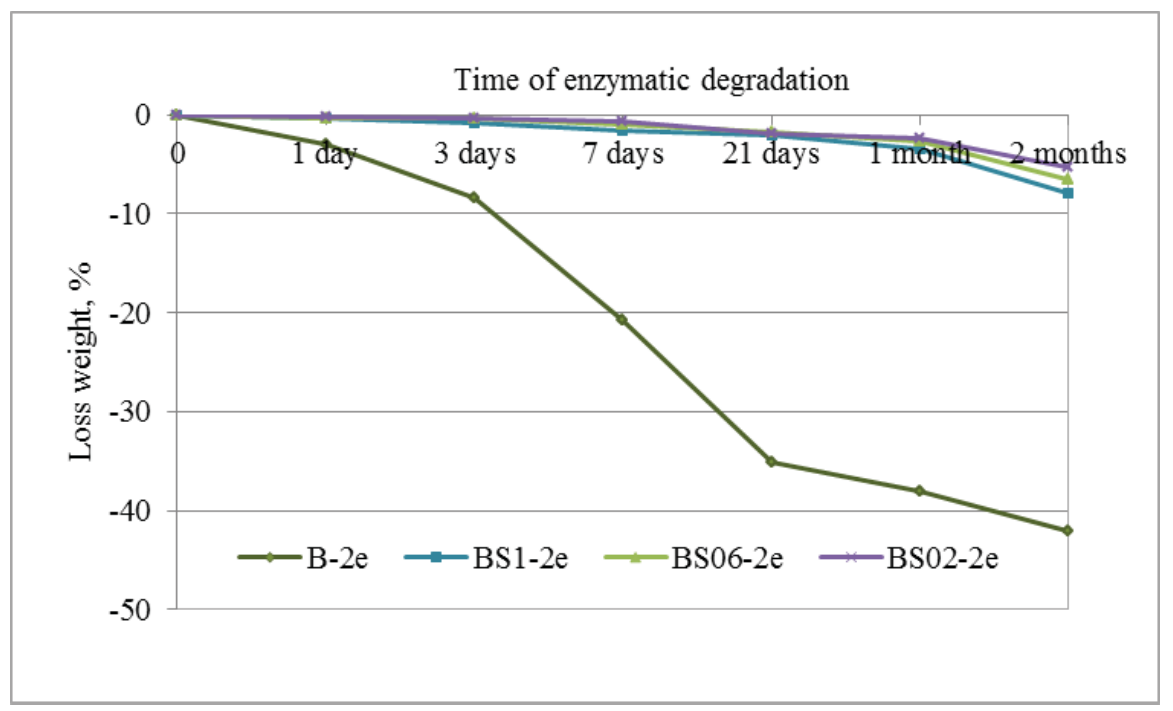

Figure 1. Losses of mass in foil B, BS02, BS06 and BS1 after two months' incubation in an enzymatic solution containing proteinase $K$

Table 2 shows the results of scanning tests of DSC differential calorimetry, the value of cold crystallization enthalpy $\left(\Delta \mathrm{H}_{\mathrm{c}}\right)$ enthalpy of melting $\left(\Delta \mathrm{H}_{\mathrm{m}}\right)$ and degree of crystallization $(\chi)$.

Table 2. Results of DSC test

\begin{tabular}{|c|c|c|c|}
\hline Sample & $\boldsymbol{\Delta H}_{\mathbf{c}}{ }^{\text {PLA }}(\mathbf{J} / \mathbf{g})$ & $\Delta \mathbf{H}_{\mathbf{m}}{ }^{{ }^{\mathrm{PLA}}}(\mathbf{J} / \mathbf{g})$ & $\chi(\mathbf{\%})$ \\
\hline B & 22.5 & 26.1 & 3.5 \\
\hline B-2e & 12.8 & 16.2 & 3.5 \\
\hline BS02 & 12.7 & 13.0 & 0.3 \\
\hline BS06 & 14.8 & 18.9 & 4.3 \\
\hline BS1 & 19.5 & 21.5 & 2.1 \\
\hline BS02-2e & 16.8 & 21.3 & 4.7 \\
\hline BS1-2e & 20.3 & 23.1 & 2.9 \\
\hline
\end{tabular}

The data presented in Table 2 show that the biostatic additive in the form of sulphanilic acid salt PHMG lowered the $\Delta \mathrm{H}_{\mathrm{c}}$ value of the foil marked with the symbols $\mathrm{BS} 02, \mathrm{BS} 06$ and $\mathrm{BS} 1$ by $42.8 \%, 33.3 \%$ and $12.2 \%$ in relations to the reference sample $\mathrm{B}$. The additive also lowered the $\Delta \mathrm{H}_{\mathrm{m}}$ value for the same samples by $50.2 \%, 27.6 \%$ and $17.6 \%$ - in relation to the control sample B. After the processes of degradation in proteinase $K$, the value of cold crystallization enthalpy and enthalpy of melting were high- er than the value of the control sample B-2e. For the sample containing the highest concentration of sulphanilic acid salt PHMG (BS1-2e), the increase amounted to $73.4 \%$ (for $\Delta \mathrm{H}_{\mathrm{c}}$ ) and $72.2 \%$ (for $\left.\Delta \mathrm{H}_{\mathrm{m}}\right)$. On the other hand, the highest change in the degree of crystallization was observed for foil BS1-2e. The increase amounted to about $71.4 \%$ in relation to the control sample B-2e.

The surface tests for samples B, BS02 and BS06 started with SEM pictures of those polymers before the process of enzymatic degradation. Figure 2 shows only the surface picture of the primary polylactide (B) because the surface pictures for samples BS02 and BS06 did not differ.

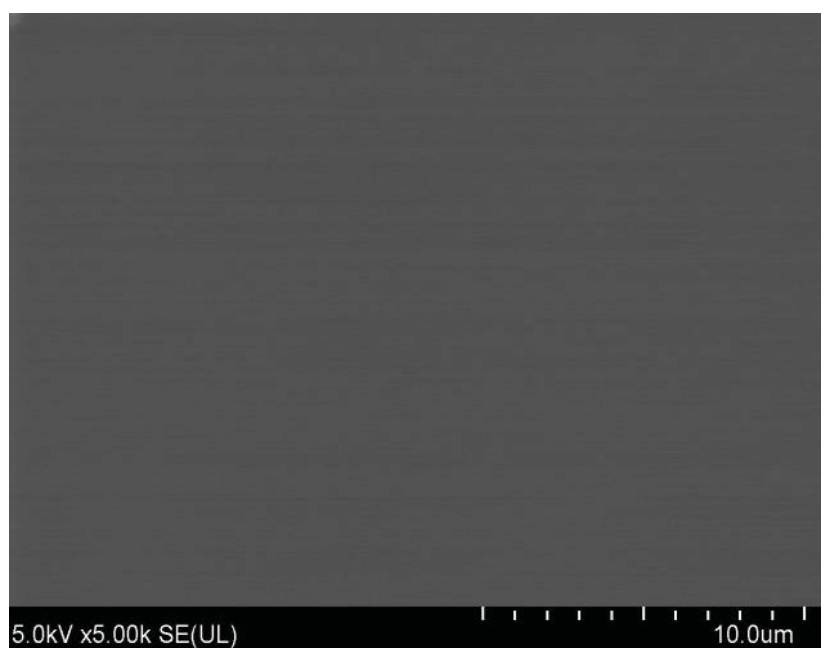

Figure 2. Surface picture of foil B before enzymatic degradation (magnification 5,000 times) 

(before enzymatic degradation) were homogeneous, uniform and smooth and there were no losses in the shape of pore and gaps.

Figure 3 shows the changes in the geometric structure of the surface of the materials B-2e, BS02-2e, BS06-2e and $\mathrm{BS} 1-2 \mathrm{e}$ after two months of degradation in proteinase $K$ solution.

Figure 3 shows that the biggest changes occurred in sample B-2e, while the changes in samples BS02-2e, BS06-2e and BS1-2e were smaller. Sample B-2e included a significant number of pores with the size of up to $1 \mu \mathrm{m}$. On the other hand, the size of the pores caused by a solution of proteinase $K$ in the foil containing sulphanilic acid salt PHMG varied from about 0.1 to $0.3 \mu \mathrm{m}$ (Fig. 3b-d). However, the number of such pores was smaller than in the
Figure 2 shows that the surfaces of the tested samples

reference sample (Fig. 3a). The differences in the surface of individual pores were connected with the number, size and depth of the created pores.

\section{Discussion}

Biodegradable polymer materials are widely used in medicine and pharmacy both as implants and drug carriers. Their biocompatibility and their capability of natural biodegradation in the human body under the influence of enzymes is undoubtedly an advantage of those materials. According to forecasts, polylactide (PLA) can replace or to a large extent exclude traditional non-biodegradable polymers used in the packaging industry (Deng \& Hao, 2001; Nampoothiri et al., 2010; Woodruff \& Hutmacher, 2010). The processes

c)
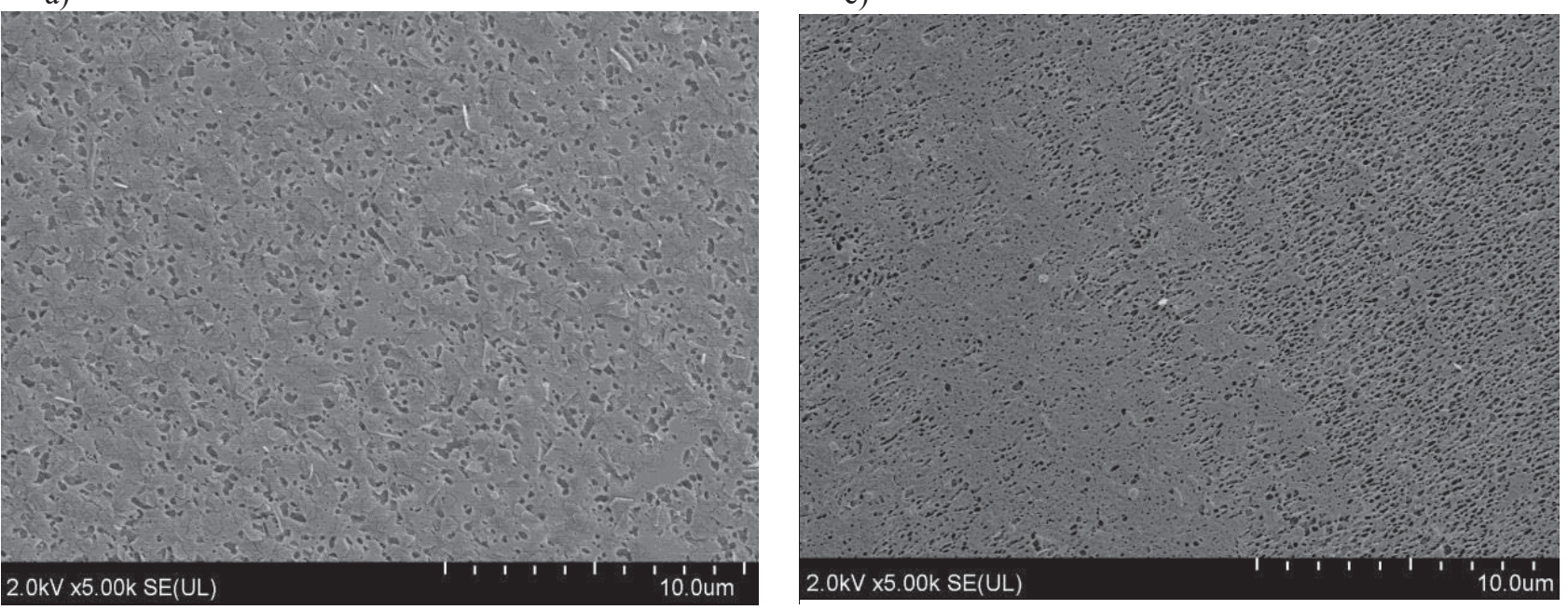

d)

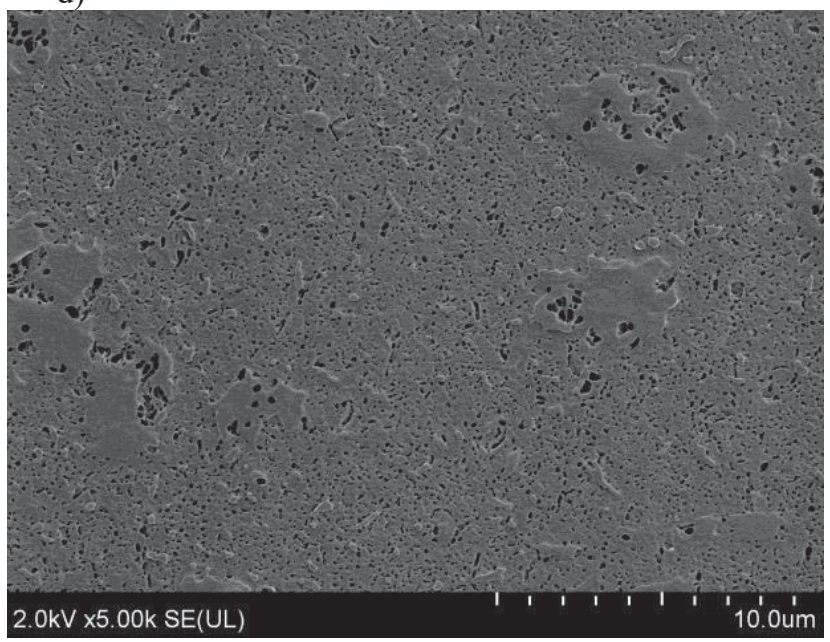

Figure 3. Analysis of the changes in the surface structure of polymer foil a) B-2e, b) BS02-2e, c) BS06-2e and d) BS1-2e after two months of enzymatic degradation with proteinase $K$ (magnification 5,000 times) 
of enzymatic biodegradation of biodegradable materials, including polylactide, have been put to many tests and their results have been published in many papers (Li et al., 2001; Yew et al., 2005; Li et al., 2007; Peng et al., 2010; Kemme et al., 2011; Zhang et al., 2011; Rodríguez-Contreras et al., 2012, Yang et al., 2012). Unfortunately, a direct comparison of the results of those tests causes problems because of the various conditions in which such tests were taken (e.g. performing the process of degradation in various environments and with the application of various enzymes) and because of the various effects of the impact of enzymes belonging to the same sub-class and produced by various microorganisms at the same time (Manna \& Paul, 2000; Chandra \& Rustgi, 1998). Tsuji et al. (2006) concluded that the following polymer properties have a significant impact on the process of polymer degradation: chemical structure, average molecular weight, wettability, content of crystalline phase and the size of crystals as well as the content and kind of additional components and the properties of the top layer. The loss in the mass of a given material during enzymatic degradation can be used as a measurement of the degree of its degradation (Richert et al., 2017; Nagata et al., 1996). The authors of many papers on various kinds of degradation also emphasize visual changes occurring on the surface of tested materials, for example, under the influence of enzymes (Richert et al., 2017; Cho et al., 2011; Wada et al., 2007). Richert et al. (2013) proved that the bacteriostatic additive in the form of sulphanilic acid salt PHMG does not decrease the PLA enzymatic degradation and thus it does not inhibit the processes of biodegradation. In addition, they proved that a bacterial biofilm easily develops on the foil containing sulphanilic acid salt PHMG, which suggests that those materials are susceptible to biodegradation, among others in compost (Richert et al., 2013).

This paper shows the results of the research into the loss of mass as well as the changes in the PLA surface structure of the biostatic composites based on polylactide and sulphanilic acid salt PHMG occurring during the degradation of those polymers under the influence of proteinase $K$. The biggest loss of mass occurs in PLA, while the loss in the composites is smaller. It means that it was PLA that underwent the fastest enzymatic degradation in the conditions of the tests. The surface topography pictures for individual pieces of tested foil confirm the results of the research into the loss of mass (Fig. 1). The earlier papers by Richert et al. (2017) confirm that two months' degradation is a sufficient period to find out if the materials being tested show susceptibility to the action of proteinase $K$.

The search for new recycling methods seems to be justified by the need to protect the natural environment. It is also necessary to look for microorganisms capable of settling environments polluted with polymer waste and to use such microorganisms and enzymes in the process of waste utilization (Emadian et al., 2017).

\section{Conclusions}

The research showed that the tested two-component composite foil containing polylactide and sulphanilic acid salt PHMG were susceptible to action of the enzyme - proteinase $K$.

- The biggest loss of mass was noticed in foil B after two months' incubation in an enzymatic solution.

- The results of the tests for the loss of mass obtained with the application of the weight method provide a good confirmation of the pictures obtained with the SEM method.

- The tests done with the application of the DSC method showed an increase in the crystallinity of composite BS1 during the process of enzymatic degradation in proteinase $K$. This phenomenon was not observed during the degradation of the other BS02 and BS06 materials, which may have been caused by the amount of the PHMG derivative used.

- Degradation of polymer material with a content of microbiological enzymes seems to be justified in the context of ecology and environmental protection.

\section{Acknowledgements}

This paper was written as part of the project pt.: "Enzymatic degradation of foil - biocidal mixtures with PLA" implemented within the framework of statutory subsidy (DS. 110107, 2017) granted to the IMPiB Institute in Torun, Poland.

\section{References}

Adamska E., Deptuła M., Filbrandt-Czaja A., Kamiński D., Lewandowska-Czarnecka A., Nienartowicz A. \& Sewerniak P., 2015, Heathlands and associated communities in Kujawy and Pomerania: management, treatment and conservation. Towarzystwo Naukowe w Toruniu, Torun.

Chandra R. \& Rustgi R., 1998, Biodegradable polymers. Progress in Polymer Science 23: 1273-1335.

Cho H.S., Moon H.S., Kim M., Nam K. \& Kim J.Y., 2011, Biodegradability and biodegradation rate of poly(caprolactone)-starch blend and poly(butylene succinate) biodegradable polymer under aerobic and anaerobic environment. Waste Management 31: 475-480.

Deng X.M. \& Hao J.Y., 2001, Synthesis and characterization of poly(3-hydroxybutyrate macromer of bacterial origin. European Polymer Journal 37: 211-214. 
Duda A. \& Penczek S., 2003, Polilaktyd [poli(kwas mlekowy)]: synteza, właściwości i zastosowania [Polylactide [poly(lactic acid)]: synthesis, properties and applications]. Polimery 1: 16-27.

Duda A., 2003, Polilaktyd - tworzywo sztuczne XXI wieku? [Polylactide - plastic of the 21st century]. Przemysł Chemiczny 8-9: 905-907.

Emadian S.M., Onay T.T., Demirel B., 2017, Biodegradation of bioplastics in natural environments. Waste Management 59: 526-536.

Górecki T., Kwiecień A., Szuster L. \& Wyrębska Ł., 2011, Poliheksametylenoguanidyna (PHMG) jako przykład nowoczesnego polimerycznego środka antybakteryjnego [Polyhexamethylene-guanidine (PHMG) as an example of a modern polymeric antibacterial agent]. Nowoczesne Wykończalnictwo szansa dla Polski i Europy, PIKTOR s.c., Łódź: 111-124.

Hildebrandt P.Ł., Wanarska M. \& Kur J.W., 2008, Mutant proteinazy K, sposób jego otrzymywania oraz sekwencje i szczepy wykorzystywane w tym sposobie [The protease $\mathrm{K}$ mutant, the method of its preparation and the sequences and strains used in this method]. Patent PL 213045.

http://www.mycobank.org [Accessed 18.02.2018].

Jeyakumar D., Chirsteen J. \& Doble M., 2013, Synergistic effects of pretreatment and blending on fungi mediated biodegradation of polypropylenes. Bioresource Technology 148: 78-85.

Kemme M., Prokesch I. \& Heinzel-Wieland R., 2011, Comparative study on the enzymatic degradation of poly(lactic-co-glycolic acid) by hydrolytic enzymes based on the colorimetric quantification of glycolic acid. Polymer Testing 30: 743-748.

Li S., Girard A., Garreau H. \& Vert M., 2001, Enzymatic degradation of polylactidestereocopolymers with predominant d-lactyl contents. Polymer Degradation and Stability 71: 61-67.

Li Z., Lin H., Ishii N., Chen G.Q. \& Inoue Y., 2007, Study of enzymatic degradation of microbial copolyesters consisting of 3-hydroxybutyrate and medium-chainlength 3-hydroxyalkanoates. Polymer Degradation and Stability 92: 1708-1714.

Lin P.L., Fang H.W., Tseng T. \& Lee W.H., 2007, Effect hydroxypatite dosage on mechanical and biological behaviuors of polilactic and composite materials. Materials Letters 61: 3009-3013.

Manna A. \& Paul A.K., 2000, Degradation of microbial poliester poly(3-hydroxybuterate) in envirommental samples and in culture. Biodegradation 11: 323-329.

Nagata M., Kiyotsukuri T., Ibuki H., Tsutsumi N. \& Sakai W., 1996, Synthesis and enzymatic degradation of regular network sliphatic polyesters. Reactive and Functional Polymers 30: 165-71.
Nampoothiri K.M., Nair N.R. \& Rojan P.J., 2010, An overview of the recent development in polilactide (PLA) research. Bioresource Technology 101: 8493-8501.

Peng H., Ling J., Liu J., Zhu N., Ni X. \& Shen Z., 2010, Controlled enzymatic degradation of poly( $\varepsilon$-caprolactone)based copolymers in the presence of porcine pancreatic lipase. Polymer Degradation and Stability 95: 643-650.

PN EN ISO 11357, 2002, Plastics - Differential scanning calorimetry (DSC) - Part 7: Determination of crystallization kinetics.

Richert A., 2017a, Właściwości bakteriostatyczne kompozytów polietylenowych [Bacteriostatic properties of polyethylene composites]. Przemysł Chemiczny 96(7): 1528-1530.

Richert A., 2017b, Właściwości strukturalne i barierowe folii polilaktydowych z bakteriocynami po biodegradacji w ekstrakcie $\mathrm{z}$ kompostu [Structural and barrier properties of polylactide films with bacteriocins after biodegradation in a compost extract]. Przemysł Chemiczny 96(6): 1313-1316.

Richert A., Olewnik-Kruszkowska E., Adamska E., 2017, Degradacja enzymatyczna bakteriobójczych kompozytów polilaktydowych [Enzymatic degradation of bactericidal polylactide composites]. Przemysł Chemiczny 96(12): 2519-2521.

Richert A., Walczak M., Swiontek Brzezińska M., 2013, The influence of modified polyhexamethylene guanidine on the biodegradation of polylactide. International Biodeterioration \& Biodegradation 84: 97-103.

Rodríguez-Contreras A., Calafell-Monfort M. \& MarquésCalvo M.S., 2012, Enzymatic degradation of poly(3hydroxybutyrate-co-4-hydroxybutyrate) by commercial lipases. Polymer Degradation and Stability 97: 597-604.

Schlegel H.G., 2003, Mikrobiologia ogólna [General Microbiology]. Wydawnictwo Naukowe PWN, Warszawa.

Tsuji H., Echizen Y. \& Nishimura Y., 2006, Enzymatic degradation of poly(L-Lactid Acid): Effects of UV irradiation. Journal of Polymers and the Environment 14: 239-248.

Vointseva I.I., Efimov K.M., Martynenko S.V. \& Skorokhodova O.N., 2006, Biocide paint and varnish composition. Patent RU 2309172.

Wada Y., Seko N., Nagasawb N., Tamada M., Kasuya K.I. \& Mitomo H., 2007, Biodegradability of poly(3-hydroxybutyrate) film grafted with vinyl acetate: Effect of grafting and saponification. Radiation Physics and Chemistry 76: 1075-1083.

Woodruff M.A. \& Hutmacher D.W., 2010, The return of a forgotten polymer-Polycaprolactone in the 21 st century. Progress in Polymer Science 35: 1217-1256.

Wyrębska Ł., Sobolewski W., Szuster L. \& Królikowski B., 2012, Sposób otrzymywania preparatu bioaktywne- 
go [The method of obtaining a bioactive preparation]. Patent PL 211371.

Yang JH., Lee Y.D., Tsai R.S. \& Tsai H.B., 2012, Enzymatic degradation of poly(l-lactide)/poly(tetramethylene glycol) triblock copolymer electrospun fiber. Materials Chemisty and Physics 133: 1127-1136.

Yew G., Mohd Yusof A.M., Mohd Ishak Z.A. \& Ishiaku U.S., 2005, Water adsorption and enzymatic degrada- tion of poly(lactid)/rise starch composites. Polymer Degradation and Stability 90: 488-500.

Zhang J., Kasuya K., Hikima T., Takata M., Takemura A. \& Iwata T., 2011, Mechanical properties, structure analysis and enzymatic degradation ofuniaxiallycold-drawn films of poly[(R)-3-hydroxybutyrateco4hydroxybutyrate]. Polymer Degradation and Stability 96: 2130-2138. 